Slobodan Cvetanović ${ }^{1}$

University of Niš, Faculty of Economics

Danijela Despotović ${ }^{2}$

Gordana Milovanović ${ }^{3}$

University of Kragujevac, Faculty of Economics
ORIGINAL SCIENTIFIC ARTICLE doi:10.5937/ekonomika1804017C

Received: August, 15, 2018 Accepted: November, 05, 2018

\title{
FOREIGN DIRECT INVESTMENTS AS A SOURCE OF FINANCING OF ECONOMIC DEVELOPMENT OF WESTERN BALKAN COUNTRIES
}

\begin{abstract}
The paper considers economic growth of five Western Balkan countries on the one hand, and on the other the affluence of direct foreign investments as one of external sources of growth in the period 2000-2017. The starting point was the attitude that due to insufficient domestic savings and engagement offoreign investments, those countries have to treat external sources of investment as a condition of permanent change of economic growth rate to a higher level, because it is obvious that after the economic crisis in 2009, the economic growth rates do not provide closure of developmental gap with EU countries. Therefore, foreign direct investments are the supplement to domestic accumulation. However, without disclaiming their benefits, it should be borne in mind that they cannot be substitution for domestic saving.
\end{abstract}

Key words: economic growth, financing of development, savings, foreign investments, Western Balkans, Economic crisis

JEL classification: 011

\section{СТРАНЕ ДИРЕКТНЕ ИНВЕСТИЦИЈЕ КАО ИЗВОР ФИНАНСИРАҢА ЕКОНОМСКОГ РАЗВОЈА ЗЕМАЉА ЗАПАДНОГ БАЛКАНА}

\begin{abstract}
Апстракт
У раду се сагледава економски раст пет земаља Западног Балкана, с једне, и прилив страних директних инвестииија, као један од екстерних извора приредног развоја ових земаља, с друге стране, у периоду 2000-2017. Пошло се од става по коме, ове земье морају, због недовољне домаће штедње, да користе страни капитал као екстерни извор финансирања развоја и да он представља услов трајног превођења њихохових стопа економског раста на виши ниво. Јер, евидентно је да стопе економског раста ових земаља након кризе из 2009. године не обезбеђују затварање развојног јаза за земљама ЕУ. У том смислу, стране
\end{abstract}

\footnotetext{
${ }^{1}$ slobodan.cvetanovic@eknfak.ni.ac.rs

2 ddespotovic@kg.ac.rs

${ }^{3}$ gordanam@kg.ac.rs
} 
директне инвестиције представљају значајну допуну домаћој акумулачији. Међутим, не оспоравајући юихову корисност, ваља имати у виду да оне не могу бити трајни супститут за недовољну домаћу итедну земаља Западног Балкана.

Кључне речи: економски раст, финансирање развоја, итедња, стране директне инвестищије, Западни Балкан, економска криза.

\section{Introduction}

Complex issues of creation of sufficient amount of domestic savings and its efficient allocation into the most productive activities are in the focus of financing of economic development (Cvetanović \& Mladenović, 2014).

Taken as a whole, market economies managed to put both domestic and foreign sources into operation of financing the quality economic growth in half-a-century long period which preceded the economic crisis in 2008. The issue of foreign direct investments (FDI) as a dominant external source of financing of development in contemporary conditions in Western Balkan countries (Albania, Bosnia and Herzegovina, Macedonia, Serbia, Montenegro and Croatia) is imposed per se before and after the outbreak of economic crisis in 2008 (Cvetanović \& Despotović, 2014).

Besides theoretical review of the significance of FDI as an external source of accumulation and indisputable precondition of permanent change of economic growth to a higher level, the paper explicates empirical data on economic growth of Western Balkan countries in the period 2000-2017. The starting point was the attitude that the period 2000-2008 was characterised by economic and especially pronounced financial globalisation worldwide, the phenomena which had obvious but unequal influence on the structure of financing of economic development in certain countries. The process of financial globalisation led to the beginning of manifestation of financial crisis during 2008, which relatively shortly evolved into the economic crisis of global character. Since it is sufficiently long interval, the issue of relative evaluation of FDI as a source of financing of economic development of Western Balkan countries seems to be very interesting.

\section{Economic growth of Western Balkan countries in the period 2000-2017}

In the observed period, 2000-2017, the economic growth of Western Balkan countries can be divided into two periods, the one before crisis and the one after the crisis in 2008. In the period 2001-2008 the countries in this region had the average economic growth rate of about $4.7 \%$. The economic growth rate in 2009 was negative in all the observed countries except Albania, and amounted from $-6.9 \%$ in Croatia (which is not considered due to its membership in EU in 2013) and -5.7\% in Montenegro until -0.9 in Macedonia. 
Table 1. Annual percentage growth rate of GDP

\begin{tabular}{|l|l|l|l|l|l|l|l|l}
\hline $\begin{array}{l}\text { Co u n t r y } \\
\text { Year }\end{array}$ & Albania & BIH & Macedonia & Montenegro & Serbia & $\begin{array}{l}\text { e } \\
\text { Balkan }\end{array}$ & Croatia \\
\hline 2000 & 6.67 & 5.50 & 4.55 & 3.10 & 7.76 & 5.5 \\
\hline 2001 & 7.94 & 4.40 & -3.07 & 1.10 & 4.99 & 3.1 & 3.76 \\
\hline 2002 & 4.23 & 5.30 & 1.49 & 1.90 & 7.12 & 4.0 & 5.25 \\
\hline 2003 & 5.77 & 4.00 & 2.22 & 2.48 & 4.42 & 3.8 & 5.56 \\
\hline 2004 & 5.71 & 6.10 & 4.67 & 4.43 & 9.05 & 6.0 & 4.08 \\
\hline 2005 & 5.72 & 8.76 & 4.72 & 4.18 & 5.54 & 5.8 & 4.16 \\
\hline 2006 & 5.43 & 5.38 & 5.14 & 8.57 & 4.90 & 5.9 & 4.79 \\
\hline 2007 & 5.90 & 5.73 & 6.47 & 6.81 & 5.89 & 6.2 & 5.15 \\
\hline 2008 & 3.76 & 5.58 & 5.47 & 7.22 & 5.37 & 5.5 & 2.05 \\
\hline 2009 & 3.35 & -2.99 & -0.36 & -5.80 & -3.12 & -1.8 & -7.38 \\
\hline 2010 & 3.71 & 0.87 & 3.36 & 2.73 & 0.58 & 2.3 & -1.42 \\
\hline 2011 & 2.55 & 0.96 & 2.34 & 3.23 & 1.40 & 2.1 & -0.33 \\
\hline 2012 & 1.42 & -0.82 & -0.46 & -2.72 & -1.02 & -0.7 & -2.24 \\
\hline 2013 & 1.00 & 2.35 & 2.93 & 3.55 & 2.57 & 2.5 & -0.65 \\
\hline 2014 & 1.77 & 1.15 & 3.63 & 1.78 & -1.83 & 1.3 & -0.10 \\
\hline 2015 & 2.22 & 3.08 & 3.84 & 3.39 & 0.76 & 2.7 & 2.35 \\
\hline 2016 & 3.35 & 3.14 & 2.92 & 2.95 & 2.80 & 3.0 & 3.17 \\
\hline 2017 & 3.84 & 3.03 & 0.02 & 4.30 & 1.87 & 2.6 & 2.78 \\
\hline
\end{tabular}

Source: World Development Indicators | Databank. (n.d.)

The dynamics of growth rate for the observed countries is illustrated by the following graph obtained by the data in Table 1 .

Figure 1: Annual percentage growth rate of GDP 2000-2016

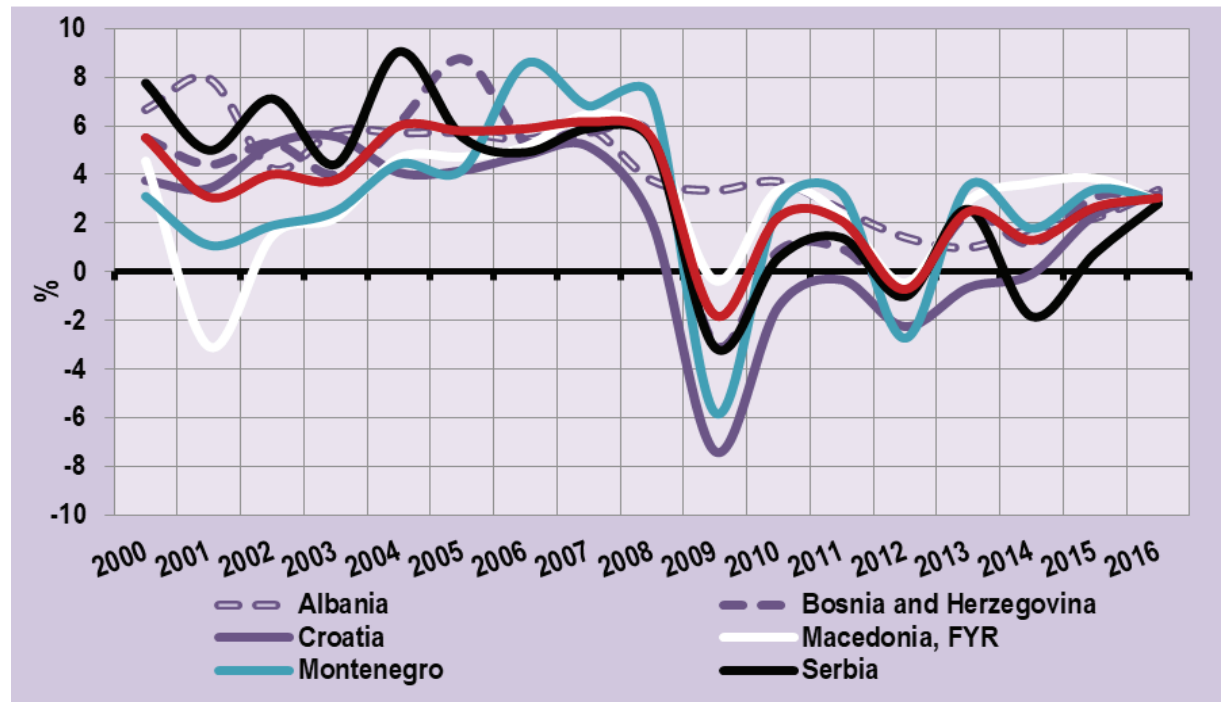


It can be noticed that the consequences of crisis were also felt during 2010, 2011 and 2012. Despite expectations that the crisis would mainly stay away from Western Balkan countries, since they were not much oriented towards export, the data show that they faced the deepest economic crisis after the collapse of SFR Yugoslavia (according of the diagram, it had the shape of double bottom crisis). A partial recovery was present in the period 20132015 , when the average growth rate was about $2 \%$. In the interval 2013-2017, only Serbia had negative growth rate of $-1.83 \%$. As an illustration, Croatia, which became the EU member in 2013 had negative economic growth rate in the whole period 2009-2014.

This time we will avoid the issue of low starting base in the calculation of chain indices as well as the fact that none of the analysed Western Balkan countries (except Albania) achieved the level of economic development in 1989. We want to concentrate on perception of flows of direct foreign investments as one of external sources of economic development.

\section{Foreign direct investments}

FDI maintain the aim of foreign entrepreneurs to realise long-lasting interest which also implies managing the property in the observed country. In general, FDI includes the freedom of foundation of an enterprise and by a rule, national treatment on the markets of other countries. They are pronouncedly characterised by taking risks and are often concentrated on certain branches of goods and service production. Besides, permanent investment is followed by technological transfer in greatest number of cases, together with the transfer of management and sales skills (Madžar, 2016, 11). They are often decisions of transnational corporations, hence they can be a part of strategy of investment and selection of location of transactional enterprise.

There are a great number of motives in capital export. They are mostly interconnected, but it is possible to list the following as the most significant:

- Higher profit or some other form of income from the invested capital;

- Cheaper labour;

- $\quad$ Lower cost of raw materials and energy;

- Completion of production process, by which the production becomes less dependent from external factors;

- $\quad$ Opening new machinery abroad in order to expand the market for own product sale;

- $\quad$ Need to increase the placement of capital goods (machines, equipment, etc.) that leads to permission to loans for foreign buyers, which is a form of capital export (Dunning, Lundan \& Sarianna, 2008).

Although there are globally the same motives that FDI tend to fulfil it should be mentioned that they all aspire to profit. FDI imply expansion of a pparent company on foreign markets, with the principal motives as follows:

Motives oriented towards the offer - FDI tend to provide production resources, most often the investments on the relation between developed countries and developing countries in order to utilize cheap raw materials and labour.

Motives oriented towards the demand - FDI are motivated by major demand on other markets, usually the dynamics of investments between the developed countries. 
Motives oriented towards the trade in which FDI are motivated by trade expansion.

Speaking of the property own by foreign companies, FDI bearers, the inspiring lever implies the so-called untouchable goods that primarily include intellectual property, consisting of technology and technological procedures, product brand as well as management experience and professional capacity of human capital. Namely, in changeable and unpredictable environment where companies search for the way to gain competitive advantage, the knowledge owed by an organisation becomes one of decisive factors in market strive for predominance, in the transition from industrial society to the society of knowledge.

FDI of two or more companies which perform successive stages of transformation to a new enterprise by joining technological unity of connected operations and work processes in organisation model of vertical integration provide foreign companies with the advantages of international specialisation and economy of scope. The most pronounced example are oil companies whose branches send raw oil to the other branches which process it, sending later thus refined oil to the those that sell it. Unlike the model of vertical integration, foreign direct investments also support the model of horizontal integration, when the similar activities are displaced in different countries.

Too strict foreign trade policy may also influence the attraction of FDI. High customs taxes can be sufficient motive for foreign companies to invest in production for local market, thus avoiding strict protective policy of the country (Vadlamannati \& Tamazian, 2009; Cvetanović, Despotović \& Mladenović, 2018).

FDI may be motivated by the care of possible exhaustion of strategic sources of supply in their own countries.

Specific FDI motives are in cheap production factors, especially when intensive work activities are in question (e.g. low wages in textile industry).

Basic classification of FDI includes two different groups:

- Greenfield investments and

- Purchase of existing plants and enterprises and overtaking their control (Cvetanović \& Mladenović, 2014)

The advantage of purchases is in gaining time and also avoidance of numerous possible problems related to the functioning of a new enterprise. The division of foreign direct investments that is often found in economic literature is the one speaking of horizontal, vertical and conglomerate FDI.

Horizontal FDI take place when an enterprise dislocates production of certain parts in foreign units. They occur by purchase of control share blocks of the enterprise which produces the same product, which results in the right to manage the company; thus a completely new enterprise is established by combining with a foreign company in the same field of production.

Vertical FDI are the form of production or some other activity organised at different locations abroad. In principle, they originate from the previously explained manner of foundation of horizontal FDI. Positive characteristics of this form of FDI are related to synchronization of a greater number of stages in the process of creation of a newly created value. Thanks to the indicated synchronization it is easier in vertical integration to solve the problems of reaction to the oscillations of offer and supply of necessary components used in the production process. However, this type of direct 
foreign investments has certain shortcomings, mainly due to the problems that arise from insufficiently good management coordination of activities at various stages of production dislocated in different countries.

In real life, conglomerate type of FDI is significantly rarely found. Their basic logic is that by diversification of production machineries in different countries, the business risk is minimized and better possibilities for realization of desirable mass of profit are created.

The most significant determinants of FDI are relative difference in income and maximization of profit in a long period, the presence on the market, availability of resources, expectations related to increase of demand and political stability (Jovanović, 2006, 556; Minović.\& Erić 2016).

The stimuli for locating FDI in certain geographical areas are the approach to increasingly developed national and international markets and stable macroeconomic environment. Stable, predictable and transparent legal situation has also an encouraging effect on foreign direct investments. This is due to simple reason that the risks are thus reduced while the profit increases. Namely, there are global regulations which control the regime of world exchange within World Trade Organisation, while no such rules are present related to FDI. The regulatory framework of FDI includes about 1600 of bilateral agreements on investments and a certain number of regional agreements.

Key motives for foreign investment are production aimed at provision of resources, provision of markets, increased efficiency and acquisition of strategic advantages.

Speaking of production aimed at provision of resources, the primary motive of foreign investment is provision of resources necessary for production at lower prices in comparison to those in the counties of parent companies that invest abroad. By following the flow of FDI in time, it is possible to conclude that raw materials were first promoted as resources, then natural materials and agricultural products. Low labour cost is also a factor that can motivate companies for foreign investments in certain circumstances. And finally, in the manufacturing conditions that are restricted by achievements of new economy, technological and managing knowledge can be a motive for investment abroad.

Provision of market as a motive of foreign direct investments is an especially significant moment when the export of products and services is no longer possible i.e. is not any more economically profitable for most diverse reasons.

The motives of foreign direct investments are frequently classified as subjective, strategic and economic.

Subjective motives of business abroad are classified into four categories:

- The invitation from high and respectable position can be the motive for taking business venture;

- Foreign investment for fear of loss of market;

- Follow-up of other companies on the areas that are attractive and interesting and

- Pressure of competitiveness on domestic market can be a motive for investment on the market of competition.

Strategic motives are related to:

- Provision of resources;

- Achievement of better efficiency;

- Gaining strategic resources;

- $\quad$ Ensuring the market (Cvetanović \& Mladenović, 2014) 
Motive for provision of resources at lower cost in comparison to the risk of investment in domestic country is a decisive stimulus when deciding about foreign direct investment. In this case, by a rule, the production based on cheap input is exported into domestic country of the investor, in order to improve competitive abilities on the markets which it supplies. Speaking of foreign direct investments, in order to achieve higher efficiency the motives and advantages are related to the economy of scope, diversification of production and risk decrease (Mencinger, 2003).

The FDI motivated by maintaining of the existing markets are by a rule aimed to the destinations where the goods were previously exported. Thus the objective of the newly founded affiliation is the continuation of servicing the local market.

Economic motives are primarily the effects of economy of scope, marketing and management experience, financial potential, technological advantages etc. literature:

Two types of FDI oriented towards higher efficiency are distinguished in the

- Bidding for labour-intensive activities in insufficiently developed, and technologically intensive in developed market economies and

- Locating branches in the countries of approximately the same level of development, when the basic motive of foreign investment is in the advantages of economy of scale, diversifications of products and differences in taste (Cvetanović \& Mladenović, 2014).

The significance of foreign direct investment aimed at acquisition of strategic advantages in current conditions of economic activities is increasingly pronounced. This is comprehensible, bearing in mind the trends in economic globalisation on the one hand, and development of technologically and scientifically intensive domains of manufacturing on the other (Carkovic \& Levine, 2005).

The total amount of FDI Inward flows in the observed Western Balkan countries amounted 70.75 billion dollars. For comparison, the amount of FDI in Croatia was 34.3 billion dollars in the same period.

Table 2. FDI Inward flows in observed countries by years (US Dollars at current prices in millions)

\begin{tabular}{|c|c|c|c|c|c|c|c|}
\hline $\begin{array}{l}\text { Country } \\
\text { Year }\end{array}$ & Albania & BIH & Montenegro & *Serbia & Macedonia & W.Balkan & Croatia \\
\hline 2000 & 144 & 146 & & 52 & 215 & 557 & 993 \\
\hline 2001 & 206 & 119 & & 177 & 447 & 950 & 1,011 \\
\hline 2002 & 133 & 265 & & 563 & 0 & 961 & 958 \\
\hline 2003 & 177 & 381 & & 1,516 & 113 & 2,188 & 1,792 \\
\hline 2004 & 346 & 511 & & 1,024 & 324 & 2,204 & 1,270 \\
\hline 2005 & 264 & 613 & & 2,078 & 96 & 3,051 & 1,786 \\
\hline 2006 & 324 & 766 & & 4,878 & 433 & 6,401 & 3,291 \\
\hline 2007 & 659 & 1,819 & & 5,340 & 693 & 8,511 & 4,633 \\
\hline 2008 & 974 & 1,002 & 960 & 3,972 & 586 & 7,494 & 5,317 \\
\hline 2009 & 996 & 250 & 1,527 & 2,896 & 201 & 5,871 & 3,059 \\
\hline 2010 & 1,051 & 406 & 760 & 1,686 & 213 & 4,116 & 1,155 \\
\hline
\end{tabular}




\begin{tabular}{|l|l|l|l|l|l|l|l|}
\hline 2011 & 876 & 497 & 558 & 4,932 & 479 & 7,342 & 1,692 \\
\hline 2012 & 855 & 395 & 620 & 1,299 & 143 & 3,312 & 1,504 \\
\hline 2013 & 1,266 & 276 & 447 & 2,053 & 335 & 4,377 & 958 \\
\hline 2014 & 1,110 & 529 & 497 & 1,996 & 272 & 4,404 & 2,870 \\
\hline 2015 & 945 & 270 & 699 & 2,347 & 240 & 4,502 & 270 \\
\hline 2016 & 1,124 & 285 & 226 & 2,299 & 397 & 4,331 & 1,745 \\
\hline Total: & 11,452 & 8,531 & 6,296 & 39,107 & 5,186 & 70,570 & 34,303 \\
\hline$* 2000$ & -2007 Serbia and Montenegro & & & & \\
\hline
\end{tabular}

Source: Foreign direct investment flows and stock. (n.d.)

Under the influence of global financial and economic crisis in Serbia, and in the whole region of Western Balkans in 2009, and especially in 2010, FDI drastically fell, which can be seen from the data in the Table 3.

In the period 2000-2006, the amount of FDI per capita shows pro-cyclic character. Thus in 2000, it amounted 49 dollars expressed in purchasing power summary for Western Balkan countries, while in 2006 it was 656 dollars, which was the greatest amount in the analysed period of eighteen years. In 2016, the FDI per capita in Western Balkan countries was 225 dollars. In Croatia it was 224 (in 2000), 1224 (in 2006) and 413 dollars (in 2016).

Table 3. FDI Inward flows in observed countries by years (US Dollars per capita at current prices)

\begin{tabular}{|c|c|c|c|c|c|c|c|}
\hline $\begin{array}{l}\text { Country } \\
\text { Year }\end{array}$ & Albania & BIH & Montenegro & *Serbia & Macedonia & W.Balkan & Croatia \\
\hline 2000 & 46 & 39 & & 5 & 107 & 49 & 224 \\
\hline 2001 & 66 & 31 & & 18 & 221 & 84 & 229 \\
\hline 2002 & 43 & 70 & & 57 & & 56 & 218 \\
\hline 2003 & 57 & 100 & & 153 & 56 & 91 & 408 \\
\hline 2004 & 111 & 134 & & 104 & 159 & 127 & 290 \\
\hline 2005 & 86 & 160 & & 212 & 47 & 126 & 408 \\
\hline 2006 & 106 & 200 & & 499 & 211 & 254 & 753 \\
\hline 2007 & 219 & 474 & & 548 & 338 & 394 & 1,063 \\
\hline 2008 & 328 & 261 & 1,550 & 436 & 285 & 572 & 1,224 \\
\hline 2009 & 340 & 65 & 2,460 & 319 & 98 & 656 & 706 \\
\hline 2010 & 362 & 106 & 1,223 & 186 & 103 & 396 & 268 \\
\hline 2011 & 304 & 130 & 896 & 547 & 232 & 421 & 393 \\
\hline 2012 & 297 & 103 & 993 & 145 & 69 & 321 & 351 \\
\hline 2013 & 439 & 72 & 716 & 230 & 162 & 324 & 224 \\
\hline 2014 & 384 & 139 & 795 & 224 & 131 & 335 & 674 \\
\hline 2015 & 326 & 71 & 1,117 & 265 & 116 & 379 & 64 \\
\hline 2016 & 387 & 75 & 361 & 261 & 191 & 255 & 413 \\
\hline
\end{tabular}

Source: Foreign direct investment flows and stock. (n.d.) 
The flow of foreign direct investments in the observed countries in the period 20002006 is illustrated in the following graph, obtained from the data in Table 3.

Figure 3: FDI Inward flows in observed countries by years (US Dollars per capita)

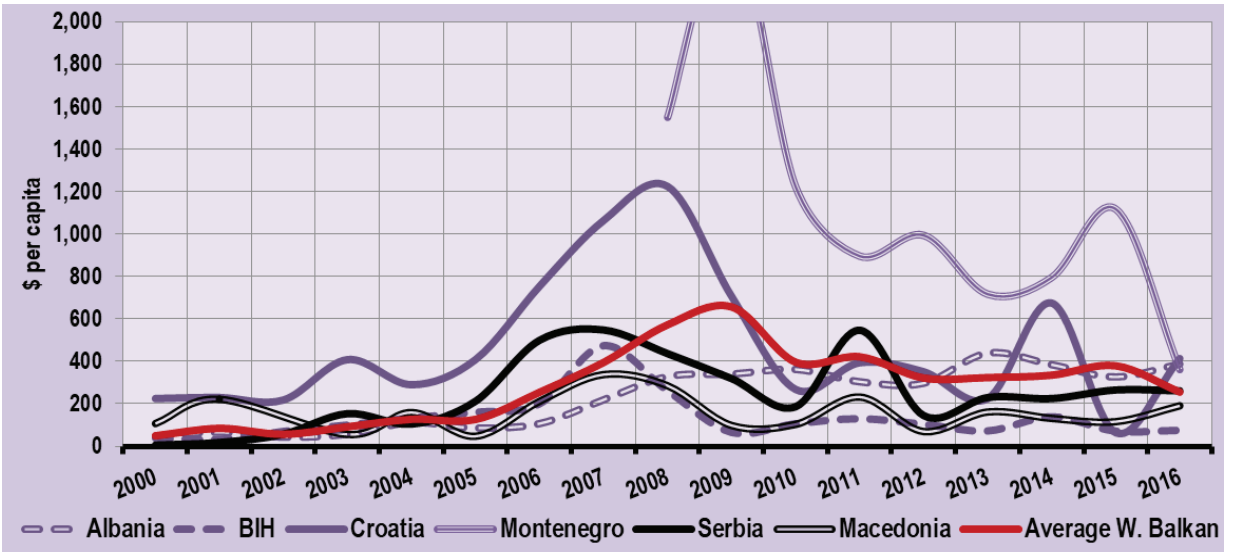

\section{FDI u \% gross investments in fixed capital}

Valuable information on the importance of FDI in financing economic development of a country is obtained by their participation on the structure of Gross Fixed Capital Formation. From the data presented in Table 4 it is clearly seen that this participation is considerable, and in Western Balkan countries as a whole it ranged between $13.5 \%$ in 2000 and $40.8 \%$ in 2009 on average.

Table 4. FDI Inward flows in observed countries by years (\% of Gross Fixed Capital Formation)

\begin{tabular}{|l|l|l|l|l|l|l|l|}
\hline $\begin{array}{l}\text { Country } \\
\text { Year }\end{array}$ & Albania & BIH & Montenegro & *Serbia & Macedonia & I.Balkan & ICroatia \\
\hline 2000 & 13.4 & 9.3 & & 3.3 & 27.9 & 13.5 & 22.9 \\
\hline 2001 & 14.2 & 7.7 & & 7.3 & 54.5 & 20.9 & 21.3 \\
\hline 2002 & 8.5 & 20.7 & & 17.1 & & 15.4 & 16.0 \\
\hline 2003 & 8.2 & 23.2 & & 32.1 & 11.3 & 18.7 & 20.0 \\
\hline 2004 & 13.7 & 20.3 & & 16.3 & 26.7 & 19.2 & 11.9 \\
\hline 2005 & 9.4 & 20.1 & & 31.9 & 8.0 & 17.4 & 15.5 \\
\hline 2006 & 9.9 & 26.4 & & 58.4 & 31.2 & 31.5 & 24.6 \\
\hline 2007 & 17.1 & 51.6 & & 42.6 & 36.5 & 36.9 & 28.8 \\
\hline 2008 & 22.3 & 22.1 & 53.8 & 28.7 & 22.9 & 30.0 & 26.9 \\
\hline 2009 & 25.3 & 7.3 & 133.5 & 29.1 & 8.7 & 40.8 & 19.4 \\
\hline 2010 & 31.0 & 13.9 & 84.9 & 18.6 & 9.8 & 31.6 & 9.1 \\
\hline
\end{tabular}




\begin{tabular}{|l|l|l|l|l|l|l|l|}
\hline $\begin{array}{l}\text { Country } \\
\text { Year }\end{array}$ & Albania & BIH & Montenegro & *Serbia & Macedonia I W.Balkan & I Croatia \\
\hline 2011 & 23.1 & 14.7 & 63.0 & 46.5 & 19.3 & 33.3 & 13.4 \\
\hline 2012 & 26.2 & 12.6 & 76.6 & 12.6 & 6.3 & 26.9 & 13.6 \\
\hline 2013 & 38.2 & 8.6 & 49.7 & 21.4 & 13.0 & 26.2 & 8.4 \\
\hline 2014 & 34.1 & 14.9 & 57.0 & 22.0 & 10.2 & 27.6 & 25.9 \\
\hline 2015 & 31.6 & 9.7 & 85.6 & 28.5 & 10.3 & 33.1 & 2.8 \\
\hline 2016 & & & & & & \\
\hline * $2000-2007$ Serbia and Montenegro & & & & \\
\hline
\end{tabular}

Source: Foreign direct investment flows and stock. (n.d.)

Figure 4: FDI Inward flows in observed countries by years (\% of Gross Fixed Capital Formation)

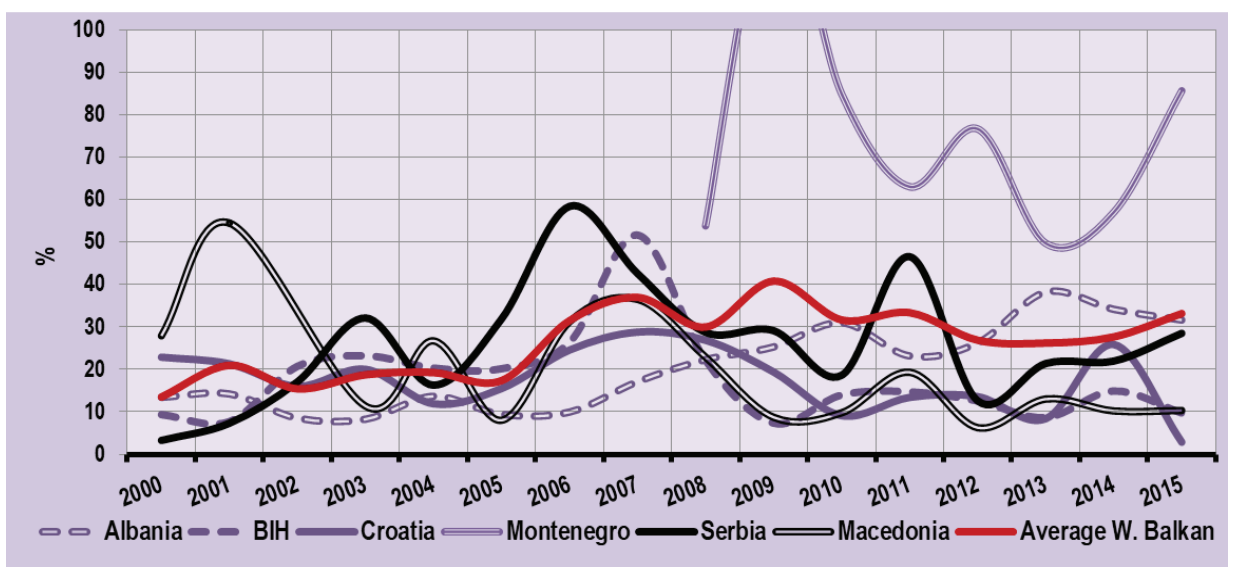

\section{Conclusion}

One of characteristic features of contemporary world economy is the increasing presence and significance of FDI. These investments provide flows of trade, capital, labour, technology, thus becoming one of basic drivers of globalization and key developmental factor of many countries. From the previously mentioned reasons, the Western Balkan countries consider the attraction of foreign capital in the form of FDI one of basic priorities of their development. According to the research conducted in this paper, in the period 2000-2016, Western Balkan countries had total affluence of FDI of about 70.5 billion US Dollars at current prices, which can be regarded insufficient as a whole, since this amount is only twice higher than affluence of FDI in Croatia. Under the influence of global financial and economic crisis in 2009 and especially in 2010, FDI drastically reduced in the Western Balkan countries.

Due to insufficient domestic savings, the Western Balkan countries have to treat the engagement of foreign capital as the condition of permanent rise of economic growth rate to a higher level. In addition, they are the bearers of a great number of technological and 
organisational innovations. However, without denying their usefulness, one should bear in mind that they cannot substitute domestic savings. Since world economic history does not know the economic development of any country without domestic savings, it is not realistic to expect FDI to by a key source of financing in the Western Balkan countries.

\section{References}

Carkovic, M., \& Levine, R. (2005). “Does Foreign Direct Investment Accelerate Economic Growth?“, in Moran et al. (eds.),Does Foreign Direct Investment Promote Development?, Washington DC, Institute for International Economics, pp. 195-220.

Cvetanović, S., \& Mladenović, I. (2014). Ekonomija kapitala i finaniranje razvoja. Niš: Sopstveno izdanje.

Cvetanović, S., \& Despotović, D. (2014). Funding Sources for the Development of Western Balkan Countries 2001-2012. Ekonomika, (3).

Cvetanović, S., Despotović, D., \& Mladenović, I. (2018). Ekonomski rast zemalja Zapadnog Balkana : Nizak kvalitet i neizgrađenost institucija kao nedostajući faktor.

U: Institucionalne promene kao determinanta privrednog razvoja Republike Srbije. Ekonomski fakultet Kragujevac, str. 83-98.

Dunning, John H., Lundan, \& Sarianna M. (2008). Multinational Enterprises and the Global Economy, Second Edition, Cheltenham, UK, Edward Elgar Publishing Limited.

Foreign direct investment flows and stock. (n.d.). Retrieved from http://unctadstat.unctad. org/wds/ReportFolders/reportFolders.aspx. UNCTAD

Jovanović, M. (2006). Evropska ekonomska integracija, Ekonomski fakultet, Beograd,. str. 556.

Madžar, Lj. (2016). Strane investicije u ekonomskoj politici Srbije, Strane direktne investicije i privredni rast u Srbiji, Beograd: Ekonomski fakultet u Beogradu, str. 11-34.

Mencinger, J. (2003). "Does foreign direct investment always enhance economic growth?“, Kyklos, Vol. 56, No. 4, pp. 491-508.

Minović, J., \& Erić, D. (2016). "Impact of Political Risk on Frontier Capital Market", Engineering Economics, Vol. 27, No. 2, pp. 151-162.

Vadlamannati, K. C., \& Tamazian, A. (2009). Growth effects of FDI in 80 developing economies: the role of policy reforms and institutional constraints. Journal of Economic Policy Reform, 12(4), 299-322.

World Development Indicators | DataBank. (n.d.). Retrieved July 12, 2018, from http:// databank.worldbank.org/data/source/world-development-indicators. World Bank

The author's biographical sketch: 